\title{
Effect of pedestrian traffic on the slip resistance and visual appearance of ceramic
}

\section{floor tiles}

\author{
Efeito do tráfego de pedestres na resistência ao escorregamento e na aparência visual de pisos \\ cerâmicos
}

Efecto del tráfico peatonal sobre la resistencia al deslizamiento y el aspecto visual de los pavimentos cerámicos

Received: 03/29/2021 | Reviewed: 04/09/2021 | Accept: 04/10/2021 | Published: 04/21/2021

\author{
Ana Virgínia Lot Le $^{1,2}$ \\ ORCID: https://orcid.org/0000-0003-3759-7034 \\ Federal University of São Carlos, Brazil \\ E-mail: anavirginia.lot@gmail.com \\ Ana Paula Margarido Menegazzo \\ ORCID: https://orcid.org/0000-0003-1222-8160 \\ Centro Cerâmico do Brasil, Brazil \\ E-mail: anapaula@ccb.org.br \\ Camila Tavares Brasileiro ${ }^{1,2}$ \\ ORCID: https://orcid.org/0000-0002-6082-404X \\ Federal University of São Carlos, Brazil \\ E-mail: camilatbrasileiro@gmail.com \\ Fábio Gomes Melchiades \\ ORCID: https://orcid.org/0000-0002-6983-4180 \\ Centro de Revestimentos Cerâmicos, Brazil \\ E-mail: tecnico@crceram.com.br \\ Anselmo Ortega Boschi ${ }^{1,2}$ \\ ORCID: https://orcid.org/0000-0003-0233-2140 \\ Federal University of São Carlos, Brazil \\ E-mail: anselmo.ufscar@gmail.com
}

\begin{abstract}
The increase of surface roughness is a common measure for improving the slip resistance of floors. Nevertheless, the surface roughness of the floors can wear out during the use. Furthermore, rough surfaces can be susceptible to dirt accumulation. As a consequence, during the use, the original slip resistance and visual appearance of the floors can be deteriorated. In this scenario, the objective of this work was to evaluate the effects of pedestrian traffic on the surface profile, slip resistance and visual appearance of commercial ceramic floor tiles. The surface profile (contact profilometer), slip resistance (pendulum method) and visual appearance (visual analysis) of different commercial ceramic floors were evaluated before and after their exposure to heavy pedestrian traffic, and the results were compared. Significant reductions of the sharpness and height of profile peaks of the surfaces, due to mechanical wear, were observed. Consequently, for all the surfaces which initially presented satisfactory slip resistance for use in slipping risk areas, this property was reduced to unsafe levels. The degree of dirt accumulation, and the consequent visual appearance deterioration, varied according to the profile characteristics of the studied floors. The best cleaning performances were found for surfaces with more spaced irregularities and wider profile valleys.
\end{abstract}

Keywords: Ceramic tiles; Ceramic floors; Surface; Cleanability; Slip resistance.

\section{Resumo}

O aumento da rugosidade superficial é uma medida comum para incrementar a resistência ao escorregamento de pisos. No entanto, a rugosidade da superfície dos pisos pode sofrer desgaste durante sua utilização. Ademais, superfícies rugosas podem ser susceptíveis ao acúmulo de sujeira. Como consequência, durante o uso, a resistência ao escorregamento e a aparência visual original dos pisos podem ser deterioradas. Nesse cenário, o objetivo deste trabalho foi avaliar os efeitos do tráfego de pedestres no perfil superficial, na resistência ao escorregamento e na aparência visual de pisos cerâmicos comerciais. O perfil superficial (perfilômetro de contato), a resistência ao

\footnotetext{
${ }^{1}$ Federal University of São Carlos, Graduate Program in Materials Science and Engineering,

Rodovia Washington Luiz, km 235 SP-310, 13565-905, São Carlos, São Paulo, Brazil.

${ }^{2}$ Federal University of São Carlos, Department of Materials Engineering,

Rodovia Washington Luiz, km 235 SP-310, 13565-905, São Carlos, São Paulo, Brazil.
} 
escorregamento (método do pêndulo) e a aparência visual (análise visual) de diferentes pisos cerâmicos comerciais foram avaliados antes e após sua exposição ao tráfego intenso de pedestre, e os resultados foram comparados. Observaram-se reduções significativas na agudez e na amplitude dos picos dos perfis das superfícies, devido ao desgaste mecânico. Consequentemente, para todas as superfícies que inicialmente apresentaram resistência ao escorregamento satisfatória para uso em áreas de risco de escorregamento, essa propriedade foi reduzida a níveis não seguros. O grau de acúmulo de sujeira, e a consequente deterioração do aspecto visual, variaram de acordo com as características do perfil dos pisos estudados. Os melhores desempenhos de limpeza foram encontrados para superfícies com irregularidades mais espaçadas e perfis com vales mais largos.

Palavras-chave: Revestimentos cerâmicos; Pisos cerâmicos; Superfície; Limpabilidade; Resistência ao escorregamento.

\section{Resumen}

El aumento de la rugosidad superficial es una medida habitual para incrementar la resistencia al deslizamiento de pavimentos. Sin embargo, la rugosidad de la superficie de los pavimentos puede desgastarse durante su utilización. Además, las superficies rugosas suelen ser susceptibles a la acumulación de suciedad. Como consecuencia, durante el uso, la resistencia al deslizamiento y la apariencia visual original de los pavimentos pueden deteriorarse. En este escenario, el objetivo de este trabajo fue evaluar los efectos del tránsito peatonal en el perfil superficial, la resistencia al deslizamiento y el aspecto visual de pisos cerámicos comerciales. El perfil de la superficie (perfilómetro de contacto), la resistencia al deslizamiento (método del péndulo) y el aspecto visual (análisis visual) de diferentes pisos cerámicos comerciales se evaluaron antes y después de su exposición al tráfico peatonal intenso y se compararon los resultados. Se observaron reducciones significativas de la agudeza y la amplitud de los picos de los perfiles de las superficies, debido al desgaste mecánico. En consecuencia, para todas las superficies que inicialmente presentaron resistencia al deslizamiento satisfactoria para uso en áreas de riesgo de deslizamiento, esta propiedad se ha reducido a niveles inseguros. El grado de acumulación de suciedad, y el consecuente deterioro visual de la apariencia, varió según las características del perfil de los pisos estudiados. Los mejores desempeños de limpieza se encontraron para superficies con irregularidades más espaciadas y perfiles con valles más anchos.

Palabras clave: Baldosas cerámicas; Pavimentos cerámicos; Superficie; Limpiabilidad; Resistencia al deslizamiento.

\section{Introduction}

Slip resistance and cleanability are among the most important technical characteristics of ceramic floor tiles. To achieve the slip resistance required for use in areas of slipping risks, it is usual to increase the roughness of the surface of the tiles. This approach has at least two undesirable consequences: 1) the surface roughness can wear out during use, and 2) rough surfaces can present low cleanability, which may lead to dirt accumulation. In both cases, the slip resistance and the visual appearance of the floor tiles can be compromised. In this scenario, the objective of this work was to evaluate the effects of pedestrian traffic on the surface profile, slip resistance, and visual appearance of commercial ceramic floor tiles.

\subsection{Slip Resistance}

Slip and fall accidents are an issue of great concern due to their health and economic implications (Chang, Matz, Grönqvist \& Hirvonen, 2010; Clarke et al., 2015; Li, Chang, Leamon, Chen, 2004; Muñoz, 2019; World Health Organization, 2007). In order to prevent these accidents, floor covering materials are assessed regarding their slip resistance, an indicative measure of the slipping risks they can represent for pedestrians, intimately related to their surface profile (Chang, 2004; Li et al., 2004; Muñoz, 2019).

The profile of a surface can be characterized by the presence of micro-irregularities, which constitute the roughness, and macro-irregularities, such as waviness and relief elements. Regarding the micro-irregularities, the specialized literature suggests that the presence of numerous peaks, preferably high and sharp, contributes to increasing the floor slip resistance by improving anchoring effects acting at the interface between the surface of the floor covering material and the shoe sole (Chang, 2004; Chang et al., 2010; Li et al., 2004; Shaw, Lemon, Thorpe, 2009; Stevension, Hoang, Bunterngchit, Lloyd, 1989). Macroirregularities, such as waves and reliefs, can also provide anchoring effects and, besides this, significantly increase the amplitude of the surface profile. 
The amplitude of the surface profile is especially relevant for floors used in wet conditions. In these cases, slipping risks can be aggravated by the presence of liquid films formed between the shoe sole and the covering material, which can prevent the contact between these two surfaces. In this sense, the chances of this floor-shoe contact not being interrupted by the liquid at the interface may be greater if the floor surface profile is constituted of high peaks. It should still be added that, although friction mechanisms are essentially related to profile peaks, the presence of valleys in the surface of a floor can contribute to increasing its wet slip resistance by providing volume for the accommodation of liquids, preventing the formation of the undesirable above mentioned liquid films (Chang, 1999; Chang, 2004; Clarke et al., 2015; Kim, 2017).

The slip resistance of floor surfaces is usually measured in the form of coefficient of friction. Among several methods prescribed by technical standards, the Pendulum, mainly due to the good correlation observed between its results and slip accidents (Clarke et al., 2015), is well accepted worldwide (ASTM, 2018; AS, 2013; BSI, 2002; BSI, 2011; UNE, 2003). The arm of the Pendulum, equipped with a rubber slider, is released from a given height to scans a length of $124 \mathrm{~mm}$ of the surface. Then, the rebound height, named Pendulum Test Value (PTV), which is approximately the dynamic friction coefficient $\mathrm{x} 100$ (Clarke et al., 2015; Muñoz, 2019), is registered. The floors are classified according to their PTV for use in different areas of slipping risks (United Kingdom Slip Resistance Group, 2000).

In this regard, it important to highlight that, according to the standards, the slip resistance of the floors is only evaluated before their use. However, high and sharp protrusions of the floor surfaces, related to friction mechanisms, can be very susceptible to abrasive wear (Parra, Gennari, Melchiades, Boschi, 2006). In turn, the possible wear of these protrusions, due to pedestrian traffic and cleaning efforts during the floor useful life, can lead to a drop in the slip resistance. Besides that, if the surfaces wear out, their visual appearance, conferred by the finishing treatments, can be compromised.

\subsection{Visual appearance / Cleanability}

Cleanability is a surface characteristic that determines the facility and efficiency of dirt and stain removal (Rambaldi, Lucchese, Engels, Bignozzi, 2019). Surfaces that cannot be easily cleaned can be susceptible to staining and soiling, which, in turn, can significantly compromise their aesthetic attributes / visual appearance. Additionally, the accumulation of dirt in surface valleys can affect the wet slip resistance of the floor by reducing the surface volume available for liquid accommodation, relevant to avoid liquid film formation, as described above.

The cleanability of a surface is also related to its texture because small nooks and crannies may allow the accommodation of contaminants that, in some cases, cannot be removed by conventional methods, like mopping. Therefore, to improve the cleaning performance of floors, product designers usually aim for surfaces with the smoothest profile that provides the required slip resistance for the safe use of the covering material.

The cleanability of the surfaces is usually evaluated in the laboratory through standardized stain-resistance tests (ASTM, 2004; ISO, 1995). The surfaces are exposed to staining agents and, subsequently, attempts are made to remove the produced stains through different cleaning procedures. Thereafter, the surfaces are classified in accordance with the easiness with which they can be cleaned and restored to their original appearance. This methodology is questionable in at least two aspects: 1) the staining agents adopted are not usual in normal use conditions, and 2) the tests are performed in brand new tiles and do not take into consideration the possible effects of use (aging by pedestrian traffic).

\subsection{Evaluation of long-term performance of ceramic floors}

The best approach to evaluate the effects of use on the performance of flooring materials is to submit the products to pedestrian traffic for a determined period of time or traffic volume and to evaluate the characteristics of interest before and after this procedure. However, it's well-known that the performance variation is strongly affected by the conditions in which 
the evaluation is done. Thus, as a general rule, this sort of evaluation considers that a good performance in a very demanding environment shall assure a good performance everywhere.

To evaluate the effects of use on the slip resistance and visual appearance of floor tiles under controlled conditions, some methods have been proposed. In essence, these methods are based on the assessment of the slip resistance of the surfaces before and after they have been subjected to wear cycles in motion machines equipped with abrasive pads (Engels, 2016; Muñoz et al., 2014; Strautins, 2008). To representatively simulate contamination conditions, since staining agents adopted in stain resistance tests are not relevant for many problematic ceramic floor applications, a mixture of peanut oil, kaolin, and soot has been reported to be used (Engels, 2016). The validation of these approaches involves the comparison of the results produced by the simulation processes with measurements made in real use conditions (pedestrian traffic).

\section{Methodology}

To study the effects of pedestrian traffic on the surface profile, slip resistance and visual appearance of ceramic floors, commercial ceramic floor tiles, with different surface finishes, listed in Table 1, were submitted to heavy pedestrian traffic in the presence of contaminants. The surface profile, slip resistance and the visual appearance of the samples were characterized before and after the experiment.

Table 1. Selected ceramic floor tiles and a brief description of their surface characteristics.

\begin{tabular}{ll}
\hline Samples & Surface description \\
\hline Glossy Polished & Glossy smooth polished surface \\
Satin & Satin smooth glazed surface \\
Glossy Wavy & Glossy wavy surface, produced by the pulverization of glaze drops \\
Natural & Natural porcelain tile surface (no finish) \\
Matt & Glazed matt surface produced by application of grits (coarse-grained crushed glass) \\
ABS & Glazed surface with ABS texture, produced with matt glaze applied in specific points \\
Wood & Glazed textured surface with wood look \\
Stone & Glazed textured surface with stone look \\
\hline
\end{tabular}

Source: Authors (2021).

\subsection{Pedestrian traffic experiment}

Three tiles of each typology listed in Table 1 were installed in an area of heavy pedestrian traffic of the student restaurant of the Federal University of São Carlos, as shown in Figure 1. During the experiment, the tiles were cleaned 5 times a week with water and soap. After 6 months, which represents the estimated traffic of 100.000 pedestrians, the tiles were removed. For simplicity, in the results of this work, the samples that had suffered the effects of the pedestrian traffic described above were referred as "aged". 
Figure 1. Pedestrian walking on the sample zone.
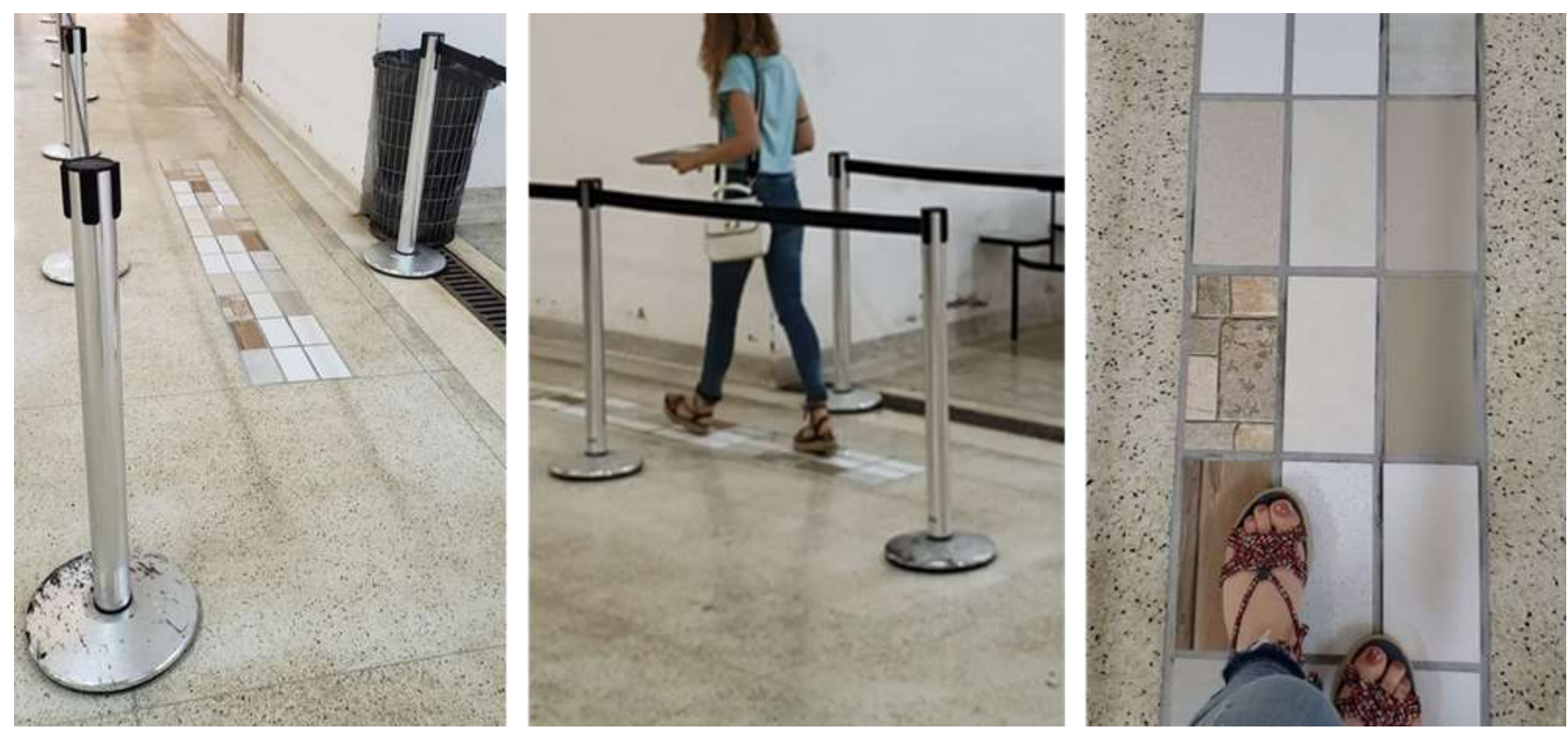

Source: Authors (2021).

\subsection{Surface Profile Characterization}

The profile of the surfaces was characterized with a contact profilometer Mitutoyo SurfTest SURFPAK Series, illustrated in Figure 2. The equipment is provided with a thin metallic stylus that slides over a length of a few millimeters on the surface. The vertical movements of the stylus are measured in relation to a reference, defined as the zero value on the vertical axis. The movements of the stylus are registered and converted into a two-dimensional primary profile of the surface. A total length of $17,5 \mathrm{~mm}$ was scanned on each surface. As observed in Figure 3, to avoid the distortions produced by the acceleration and deceleration of the car that moves the probe over the sample, a segment of 2,5 mm was discarded from each extremity of the scanned length. Thereafter, the intermediate segment (evaluation length) of 12,5 mm was split into 5 equal fragments of 2,5 mm called cut-offs. To minimize influences of form deviations, the profilometer software removed the profile irregularities with wavelengths higher than the length of these cut-offs. In the center of the obtained filtered profile, the mean line was traced, so that the sum of the upper and lower areas in relation to this line were equivalent. Finally, the parameters listed in Table 2, which quantify different characteristics of the obtained profile, were determined by the profilometer software. Six measurements were carried out on each surface for the calculus of the average value of these parameters. 
Figure 2. Mechanical contact profilometer.
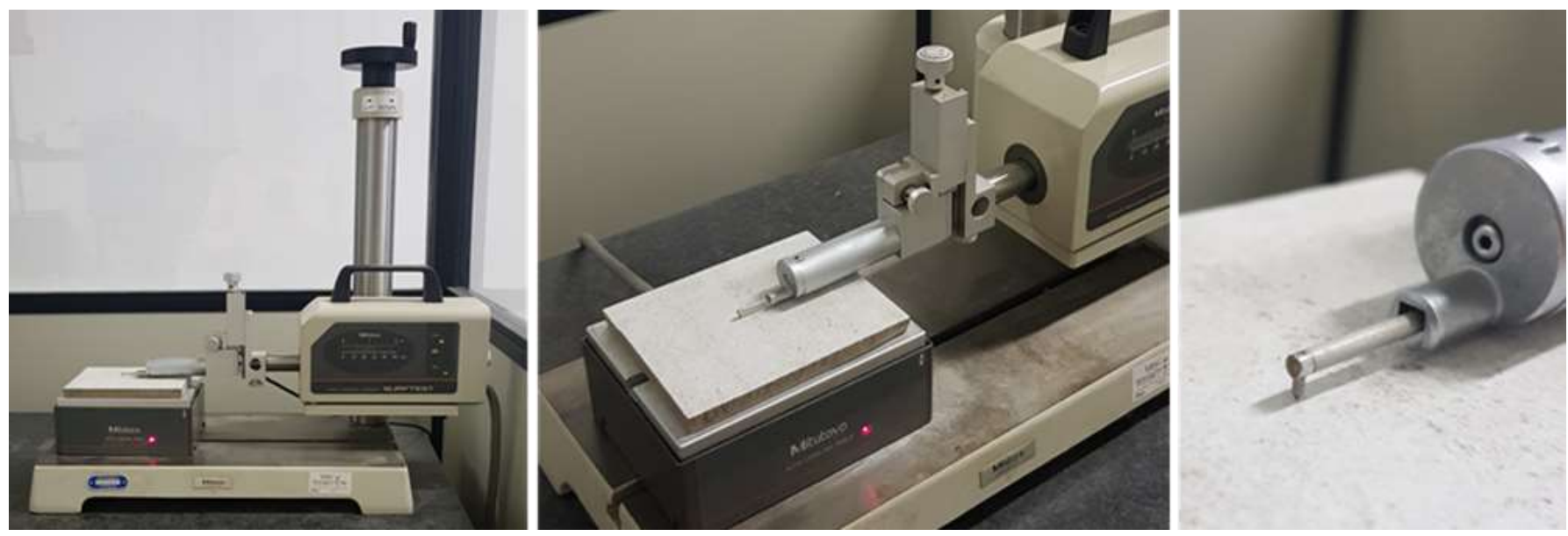

Source: Authors (2021).

Figure 3. Primary and filtered profiles obtained by the mechanical contact profilometer.

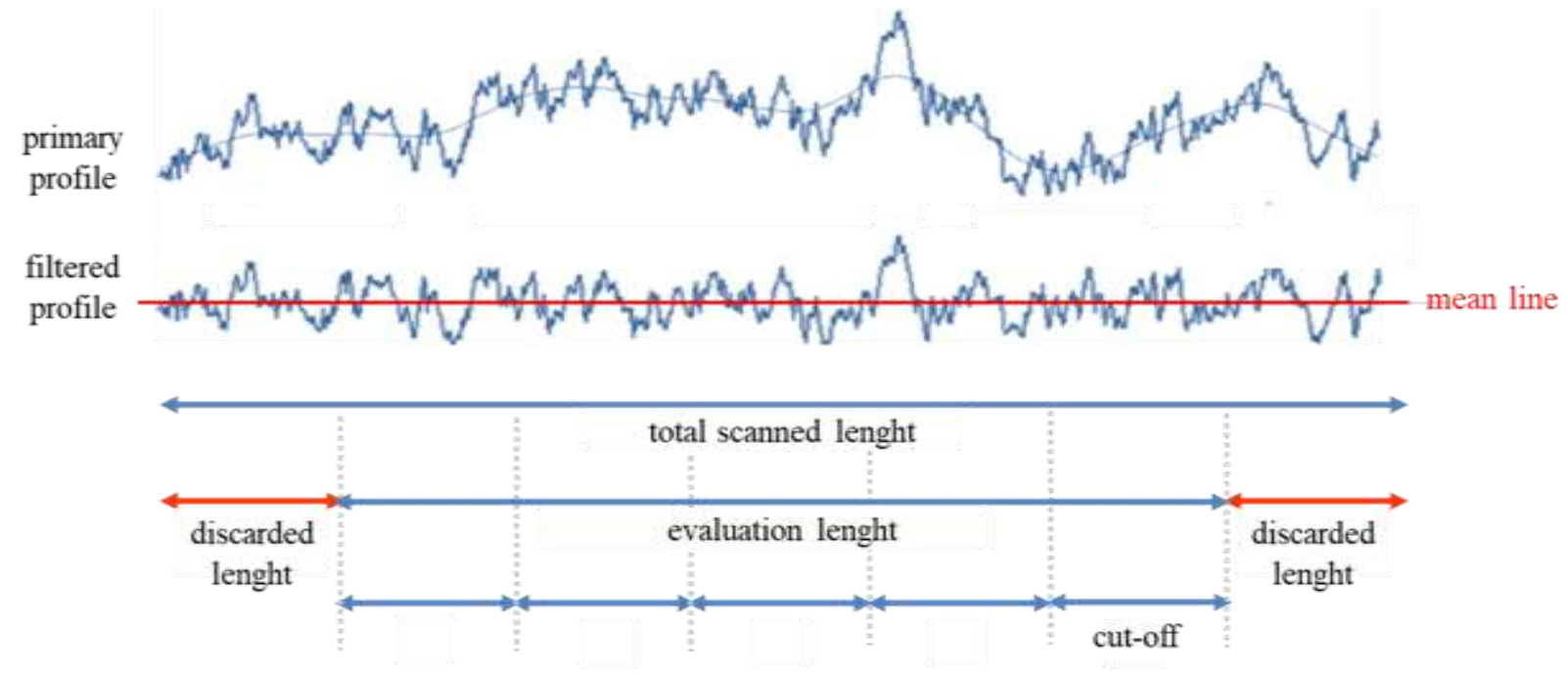

Source: Prepared by the authors from Carpinetti, Gonçalves Filho, Porto, Jasinevicius (2000).

Table 2. Roughness parameters determined by the contact profilometers.

\begin{tabular}{ll}
\hline Parameter & Descrition \\
\hline $\mathrm{Ra}$ & arithmetical mean of surface heights of the profile; mean roughness \\
$\mathrm{Rpm}$ & average of the maximum peak height in each cut-off length \\
$\mathrm{Rvm}$ & average of the maximum valley depth in each cut-off length \\
$\lambda \mathrm{a}$ & arithmetical mean wavelength of the profile \\
$\Delta \mathrm{a}$ & arithmetical mean profile slope \\
$\mathrm{Rk}$ & core roughness height (height of the central zone of the material ratio curve of the surface) \\
$\mathrm{Rpk}$ & reduced peak height (height of the peak zone of the material ratio curve of the surface) \\
$\mathrm{Rvk}$ & reduced valley depth (height of the valley zone of the material ratio curve of the surface) \\
\hline
\end{tabular}

Source: Prepared by the authors from Chang (2004) and Mitutoyo America Corporation (1994). 
The obtention of the parameters Rk, Rpk and Rvk from material ratio curves is detailed in Figure 4. A material ratio curve is a graphical representation of the material ratio, $\mathrm{mr}(\%)$, in relation to the profile level, considering $\mathrm{mr}=0 \%$ at $\mathrm{the}$ highest point of the profile and $\mathrm{mr}=100 \%$ at the lowest point. A straight line with the lowest slope possible is drawn on the curve passing through two points of $\mathrm{mr}$ values distancing each other by $40 \%$. This line intersects the axes $\mathrm{mr}=0 \% \mathrm{and} \mathrm{mr}=$ $100 \%$ at two points that define the central zone of the roughness, with amplitude Rk. Now, considering A1 the area between the curve and the upper limit of the central zone and A2 the area between the curve and the lower limit of this zone, then Rpk and Rvk are each calculated as the heights of the green and blue right-angle triangles of the Figure 4, which are constructed to have equivalent areas to A1 and A2, respectively (Mitutoyo America Corporation, 1994).

Figure 4. The material ratio curve of a surface and the definition of Rk, Rpk and Rvk parameters.

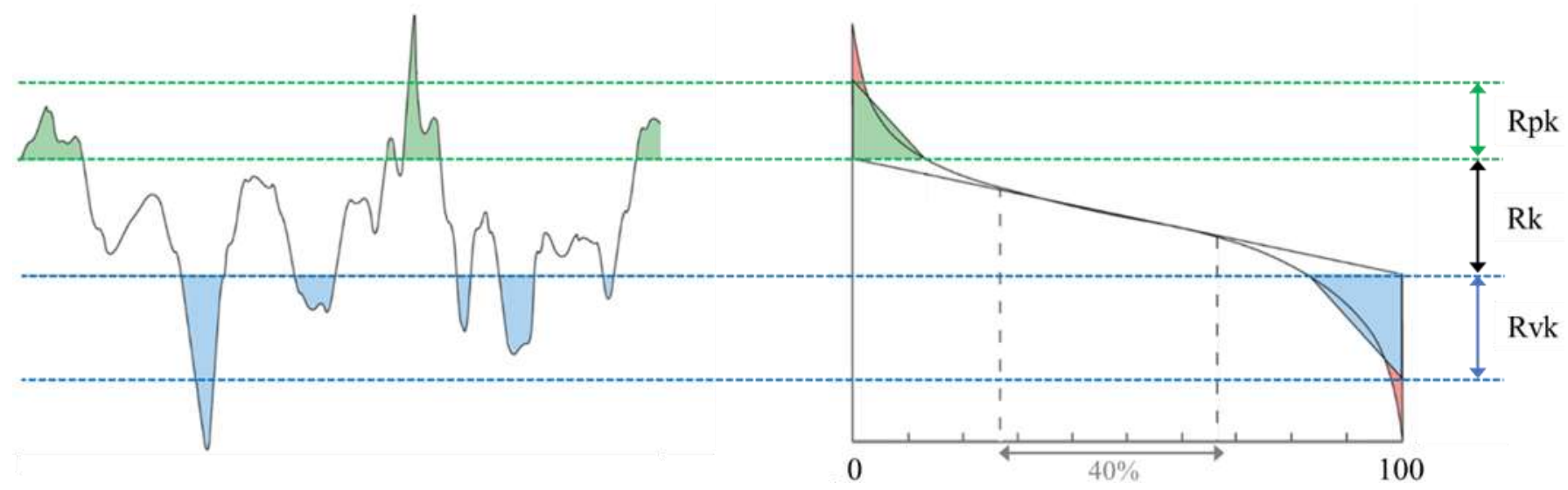

Source: Prepared by the authors from Olympus Corporation (2021).

\subsection{Slip Resistance Characterization}

The slip resistance of the surfaces was evaluated through the pendulum method, previously described, according to procedures detailed in the UNE ENV 12633:2013 (UNE, 2003), with measurements done on wet surfaces.

\subsection{Visual Appearance Characterization}

The evaluation of the visual appearance of the tiles, before and after the experiment, was performed by 12 volunteers. The volunteers assigned a grade to the surfaces, varying between 1 and 5 in accordance with the intensity of their visual appearance variation, with 5 representing no variation and 1 representing the greatest variation observed. The importance of this test is that it expresses the user's perception of the performance of the tiles in relation to this variable.

\section{Results and Discussion}

\subsection{Surface Profile Characterization}

Figure 5 presents the filtered profiles of the samples listed in Table 1, obtained by the contact profilometer, before and after the pedestrian traffic experiment. 
Figure 5. Original (blue) and aged (red) filtered profiles (length: 12,5 mm) of the surfaces listed in Table 1.

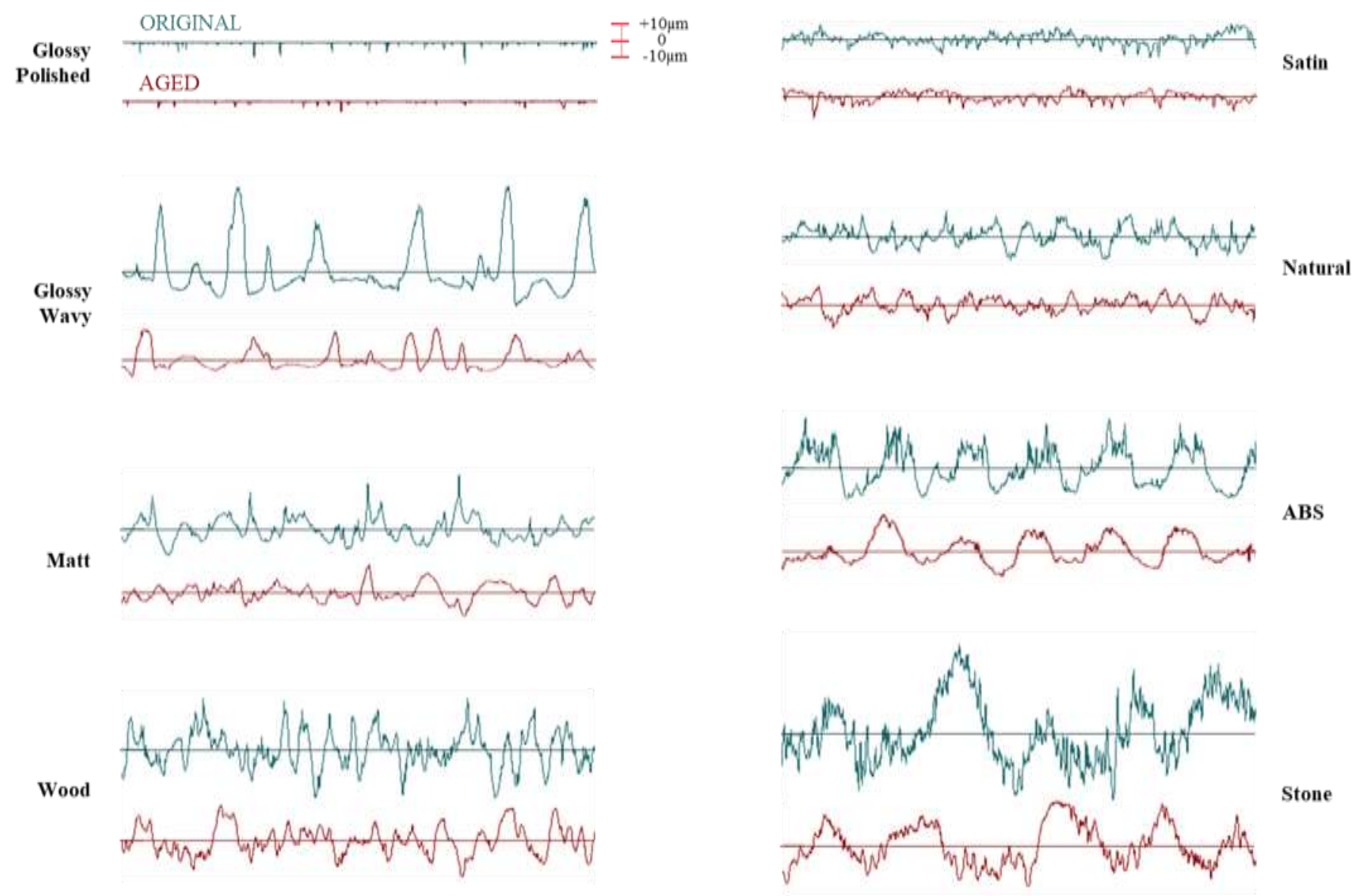

Source: Authors (2021).

The original profiles of the samples Glossy Polished and Satin showed to be characterized by smaller amplitude in comparison to those of the other surfaces. The surface profile of the Glossy Polished sample also differed from the others by being essentially constituted by valleys, which correspond to pores opened by the polishing finish applied on this surface. Conversely, the surface profile observed for the sample Matt was characterized, predominantly, by the presence of sharp peaks, with a more regular valley region. The Glossy Wavy also presented a profile constituted by peaks. However, in this case, these peaks seemed to correspond not to roughness, but waviness elements.

A high number of sharp peaks per unit length was observed in the original surface profiles of samples Natural and Wood. However, the profile of the surface Wood presented considerably higher amplitude. The original surface profiles of samples ABS and Stone, besides presenting a high number of sharp peaks per unit length, also presented regularly spaced waviness protuberances.

Analyzing the aged profiles, it was possible to observe the effect of pedestrian traffic in the original profiles of the studied samples. In general, as expected, the visual comparison of the original and aged surface profiles showed an evident reduction of the sharpness and height of the peaks, resulting from mechanical wear. The possible alteration of the profiles due to the accumulation of dirt in the valleys was not observed.

Table 3 presents the parameters calculated from the filtered surface profiles of the original and aged samples, as well as their percentual variation. 
Table 3. Roughness parameters calculated from the filtered profiles of the original and aged samples listed in Table 1 and the respective percentual variation.

\begin{tabular}{|c|c|c|c|c|c|c|c|c|c|}
\hline & & $\begin{array}{l}\text { Glossy } \\
\text { Polished }\end{array}$ & Satin & $\begin{array}{l}\text { Glossy } \\
\text { Wavy }\end{array}$ & Natural & Matt & ABS & Wood & Stone \\
\hline \multirow[t]{3}{*}{$\mathrm{Ra}(\mu \mathrm{m})$} & Original & 0,3 & 2,6 & 8,0 & 4,9 & 6,3 & 9,1 & 8,2 & 12,7 \\
\hline & Aged & 0,3 & 2,2 & 5,1 & 3,8 & 4,4 & 7,1 & 6,7 & 8,9 \\
\hline & Variation & $0 \%$ & $-15 \%$ & $-36 \%$ & $-22 \%$ & $-30 \%$ & $-22 \%$ & $-18 \%$ & $-30 \%$ \\
\hline \multirow[t]{3}{*}{$\operatorname{Rpm}(\mu \mathrm{m})$} & Original & 0,4 & 7,3 & 29,2 & 15,7 & 20,6 & 24 & 27,1 & 36,6 \\
\hline & Aged & 0,4 & 5,4 & 16,3 & 9,5 & 11,1 & 17,4 & 16,8 & 22,1 \\
\hline & Variation & $0 \%$ & $-26 \%$ & $-44 \%$ & $-39 \%$ & $-46 \%$ & $-28 \%$ & $-38 \%$ & $-40 \%$ \\
\hline \multirow[t]{3}{*}{$\operatorname{Rvm}(\mu \mathrm{m})$} & Original & 8,0 & 9,1 & 14,3 & 13,2 & 14,9 & 16,9 & 21,7 & 33,7 \\
\hline & Aged & 5,7 & 8,8 & 10,1 & 10,2 & 11,5 & 15,7 & 18,3 & 23,7 \\
\hline & Variation & $-29 \%$ & $-3 \%$ & $-29 \%$ & $-23 \%$ & $-23 \%$ & $-7 \%$ & $-16 \%$ & $-30 \%$ \\
\hline \multirow[t]{3}{*}{$\Delta \mathrm{a}\left({ }^{\circ}\right)$} & Original & 2,4 & 5 & 4,2 & 7,4 & 4,7 & 7,8 & 9,7 & 17,3 \\
\hline & Aged & 2,2 & 3,9 & 2,9 & 4,4 & 3,2 & 4,8 & 5,9 & 9,2 \\
\hline & Variation & $-8 \%$ & $-22 \%$ & $-31 \%$ & $-41 \%$ & $-32 \%$ & $-38 \%$ & $-39 \%$ & $-47 \%$ \\
\hline \multirow[t]{3}{*}{$\lambda \mathrm{a}(\mu \mathrm{m})$} & Original & 49 & 186 & 665 & 243 & 489 & 405 & 305 & 265 \\
\hline & Aged & 62 & 205 & 582 & 297 & 504 & 546 & 408 & 356 \\
\hline & Variation & $27 \%$ & $10 \%$ & $-12 \%$ & $22 \%$ & $3 \%$ & $35 \%$ & $34 \%$ & $34 \%$ \\
\hline \multirow[t]{3}{*}{$\mathrm{Rk}(\mu \mathrm{m})$} & Original & 0,4 & 8,2 & 18,2 & 16,2 & 20,2 & 25,3 & 26,7 & 41,3 \\
\hline & Aged & 0,4 & 6,8 & 12,0 & 12,4 & 13,7 & 23,2 & 22,2 & 28,7 \\
\hline & Variation & $0 \%$ & $-17 \%$ & $-34 \%$ & $-23 \%$ & $-32 \%$ & $-8 \%$ & $-17 \%$ & $-31 \%$ \\
\hline \multirow[t]{3}{*}{$\operatorname{Rpk}(\mu \mathrm{m})$} & Original & 0,3 & 3,0 & 23,5 & 6,4 & 9,0 & 10,1 & 11,6 & 15,0 \\
\hline & Aged & 0,2 & 2,0 & 11,6 & 4,0 & 5,0 & 7,9 & 6,8 & 9,9 \\
\hline & Variation & $-33 \%$ & $-33 \%$ & $-51 \%$ & $-38 \%$ & $-44 \%$ & $-22 \%$ & $-41 \%$ & $-34 \%$ \\
\hline \multirow[t]{3}{*}{$\operatorname{Rvk}(\mu \mathrm{m})$} & Original & 2,4 & 4,0 & 8,0 & 6,3 & 6,1 & 6,4 & 9,6 & 15,5 \\
\hline & Aged & 2,4 & 3,8 & 6,2 & 4,3 & 6,1 & 6,6 & 7,8 & 12,2 \\
\hline & Variation & $0 \%$ & $-5 \%$ & $-23 \%$ & $-32 \%$ & $0 \%$ & $3 \%$ & $-19 \%$ & $-21 \%$ \\
\hline
\end{tabular}

Source: Authors (2021).

In agreement with the results of the visual comparison of the original and aged profiles, a general reduction of all parameters related to the amplitude of the surface profile irregularities ( $\mathrm{Ra}, \mathrm{Rpm}, \mathrm{Rvm}, \mathrm{Rk}, \mathrm{Rpk}$ and Rpm) was observed. Besides this, the average profile slope $(\Delta \mathrm{a})$ was significantly reduced. The expressive decrease observed for the parameter $\Delta \mathrm{a}$, as well as for the parameter Rpm and Rpk, related to the amplitude of peaks, reveal the high susceptibility of high and sharp profile saliences to be removed by mechanical efforts. 


\subsection{Slip Resistance Variation}

The slip resistance of the original and aged surfaces, determined by the pendulum method, is shown in Figure 6. In this part of the study, among the samples listed in Table 1, only those which initially attended the usual slip resistance requirement for use in areas of slipping risks (PTV $\geq 36$ ) were considered.

Figure 6. Slip resistance of the original and aged surfaces listed in Table 1 which initially presented the minimum PTV required for use in areas of slipping risks ( $\mathrm{PTV}=36$, represented by the red dashed line) and the percentual variation.

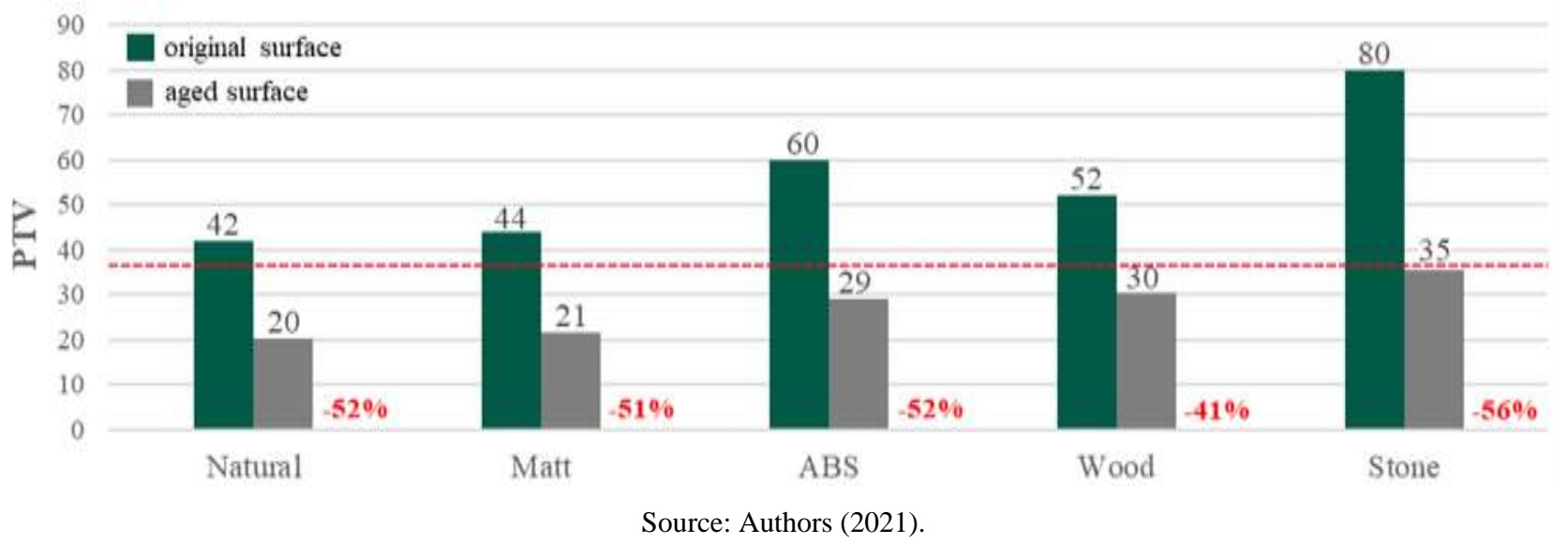

The slip resistance of the original products Natural, Matt, ABS, Wood and Stone surpassed the minimum PTV = 36 recommended for use in areas of slipping risks. However, after the pedestrian traffic experiment, the slip resistance of all the products decreased below this safety limit. It is interesting to observe that the important superiority of the slip resistance of the original products $\mathrm{ABS}$ and Stone became relatively small after the aging process. It is also important to consider that, as mentioned previously, the aging process to which the products were submitted was quite extreme, from the point of view of the volume of pedestrian traffic and contact with contaminants. Therefore, a mitigating aspect for the expressive reduction of the slip resistance presented in Figure 6 is the fact that this shall only occur in areas of heavy pedestrian traffic, a condition that could be prevented with a proper architectonic project.

\subsection{Slip resistance Variation $x$ Profile}

The reasons behind the satisfactory slip resistance of the original products Natural, Matt, ABS, Wood and Stone were addressed in a previous work (Lot, Menegazzo, Brasileiro, Melchiades, Boschi, 2021). It was found that some of the most important characteristics of the surface profile of the flooring material to assure a high slip resistance are the amplitude and the presence of an elevated number of sharp peaks per unit length, which is in agreement with other relevant studies (Chang, 2004; Chang et al., 2010; Li et al., 2004; Shaw et al., 2009; Stevension et al., 1989). Considering that the pedestrian traffic aging process produced an important reduction of the amplitude and sharpness of the surfaces profile peaks, as can be seen in Figure 5, the reduction of the slip resistance observed in Figure 6 was expected.

Figure 7 presents the variation of slip resistance of the original and aged products with the parameter Ra, that represents the arithmetical mean of surface heights of the profile, also known as mean roughness. For the proper interpretation of these results, the regression analysis method, in which the coefficient of determination - $\mathrm{R}^{2}$ - expresses how well a statistical model fits the data, was used. 
Figure 7. PTV and Ra values for the original and aged samples listed in Table 1 which initially presented the minimum PTV required for use in areas of slipping risks $(\mathrm{PTV}=36)$, with the correspondent linear regression line and the coefficient of determination $\mathrm{R}^{2}$.

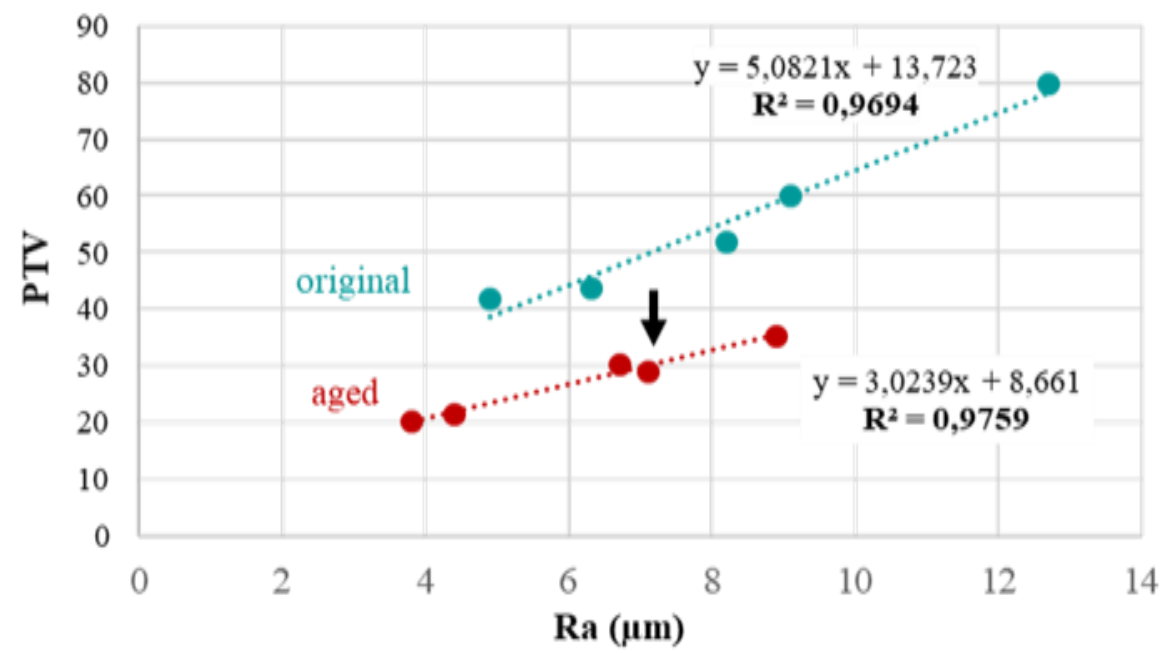

Source: Authors (2021).

As can be seen, for the original and aged products, the fitting of the linear tendency lines is quite good and shows that the slip resistance increases with the increase of the Ra parameter. This is also in agreement with other studies (Chang, 2004; Chang et al., 2010; Li et al., 2004; Lot et al., 2021; Shaw et al., 2009; Stevension et al., 1989). The figure also shows that the decrease of the slip resistance produced by the aging process was greater in the samples that originally presented higher slip resistance and Ra values. Similar results were observed for PTV values in relation to the parameters Rpm, $\Delta \mathrm{a}$ and Rpk.

\subsection{Visual Appearance Variation}

For comparison, Figure 8 presents images of the original and aged surfaces of the tiles listed in Table 1.

Figure 8. Representative images of original and aged surfaces listed in Table 1.
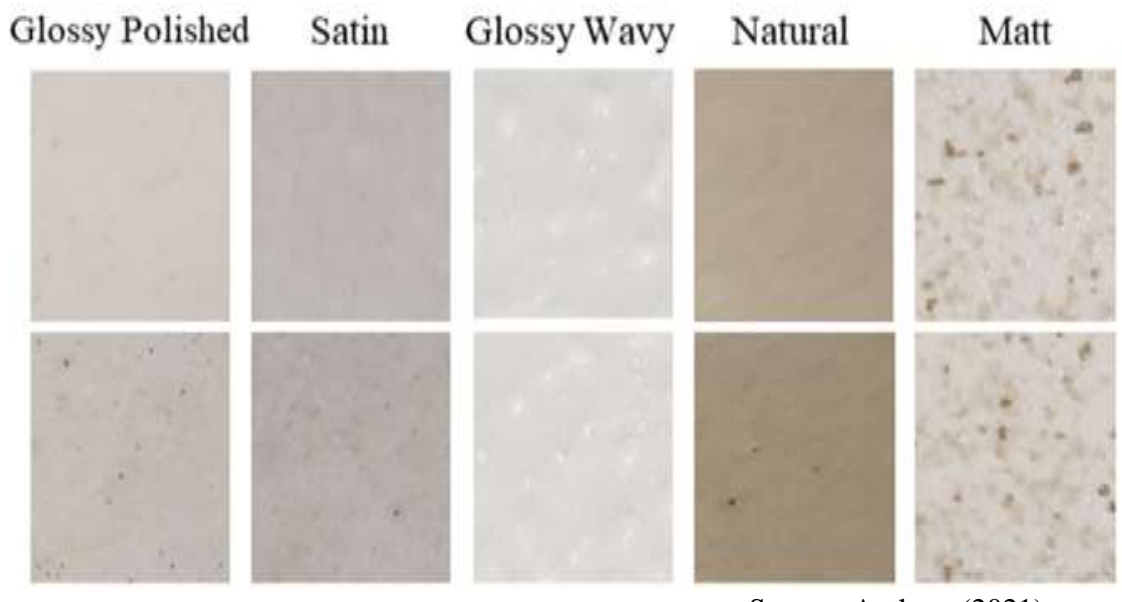

ABS
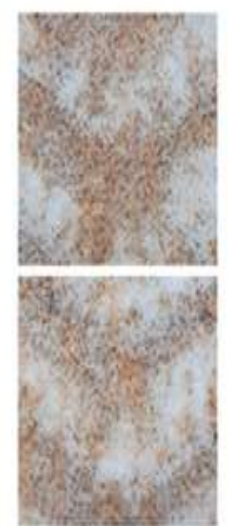

Wood
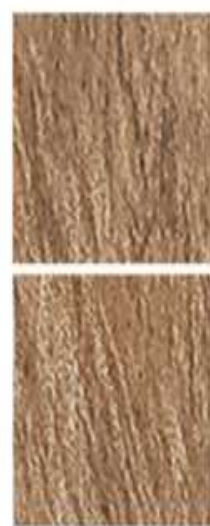

Stone
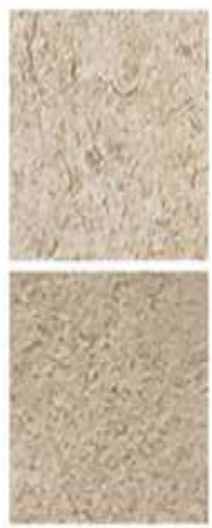

Source: Authors (2021).

The surfaces Glossy Polished, Satin, Natural, and Stone presented quite noticeable visual appearance variation regarding their color. Furthermore, black spots were observed on the aged surfaces of these samples. These changes, therefore, seemed to be associated with the accumulation of dirt. 
Regarding possible effects of wear, only the Glossy Polished surface showed to be affected. Although it cannot be visualized in Figure 8, this surface had its highly reflective glossy aspect, conferred by the polishing finish, compromised by the appearance of small scratches after the pedestrian traffic experiment.

The average grades attributed by the volunteers to the intensity of the variation of the visual appearance of the surfaces are presented in Table 4.

Table 4. Average of the grades assigned by volunteers to the samples listed in Table 1, varying between 1 and 5 , in accordance with the intensity of their visual appearance variation after the pedestrian traffic experiment. The grade 5 represents no variation and the grade 1 represents the greatest variation observed.

\begin{tabular}{ccccccccc}
\hline & $\begin{array}{c}\text { Glossy } \\
\text { Polished }\end{array}$ & Satin & $\begin{array}{c}\text { Glossy } \\
\text { Wavy }\end{array}$ & Natural & Matt & ABS & Wood & Stone \\
\hline Average grade & 1,3 & 2,9 & 4,6 & 2,1 & 5,0 & 3,3 & 3,8 & 1,0 \\
\hline
\end{tabular}

Source: Authors (2021).

Considering that dirt accumulation proved to be the main factor responsible for the visual appearance variation observed for the studied surfaces, the volunteers were instructed to grade the samples considering, essentially, surface changes related to this factor (color changes and appearance of dirt spots). Thus, the grades presented in Table 4 can be interpreted as an indicative measure of the cleanability of the surfaces. The Glossy Wavy and Matt surfaces, which did not present evident visual appearance variation in Figure 8, received the higher grades $(4,6$ and 5,0). Therefore, these results suggest that these two surfaces present the best cleaning performances among the studied tiles.

\subsection{Profile x Visual Appearance Variation}

From the original profiles of the samples Satin, Natural and Stone (Figure 5), it can be assumed that the evident dirt accumulation noticed for these floors (Figure 8 and Table 4) may be associated to the presence of numerous microirregularities close to each other on these surfaces. This is plausible since between close irregularities, narrow gaps hardly accessible by cleaning mechanisms - and, therefore, favorable to the accumulation of contaminants - are formed. In the same way, the narrow valleys constituting the profile of the Glossy Polished surface, correspondent to pores opened by the polishing finish applied to this surface, also can act as dirt concentrators. This explains the presence of numerous dark spots in the photograph of the aged surface of this sample, observed in Figure 8.

Correlations between the grades presented in Table 4 and the roughness parameters determined for the original studied surfaces, listed in Table 3, were investigated through regression analysis.

As seen in Figure 9a, a reasonable linear correlation $\left(R^{2}=0,7679\right)$ was found between the grades presented in Table 4 and the ratio between the roughness parameters $\lambda \mathrm{a}$, the average wavelength of the profile, and Rvk, the height of the valley zone on the material ratio curve, calculated from the profiles of the original samples. The analysis of the graph also shows that the results of the sample Wood deviate from the trendline fit to the data, lowering the coefficient of determination $\left(\mathrm{R}^{2}\right)$ of the linear regression. However, it is believed that there may have occurred an overestimation of the grade atributted to this sample (Table 4) due to posible difficulties in the visual perception of dirt due to the surface brown color. As observed in Figure 9b, when sample Wood was not considered in the analysis, the fitting of the linear regression was excelent $\left(R^{2}=0,9736\right)$. The randomness of the points in the correspondent residual plot confirmed the good fit of the statistical model represented by the equation presented in Figure 9b. 
Figure 9. Average grades attributed in the visual appearance variation analysis after the pedestrian traffic experiment and original $\lambda \mathrm{a} / \mathrm{Rvk}$ values for samples listed in Table 1 (a) and for the same group of samples excluding the surface Wood (b), with the correspondent linear regression lines and the coefficients of determination $\mathrm{R}^{2}$.

a)

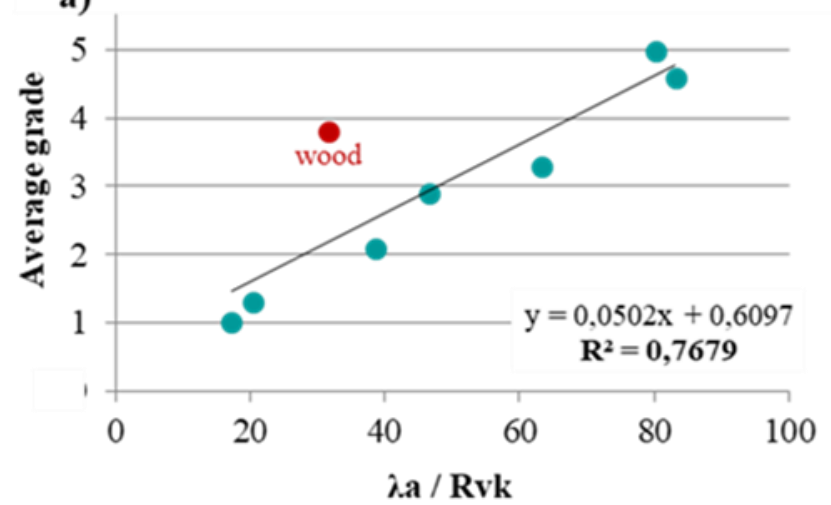

b)

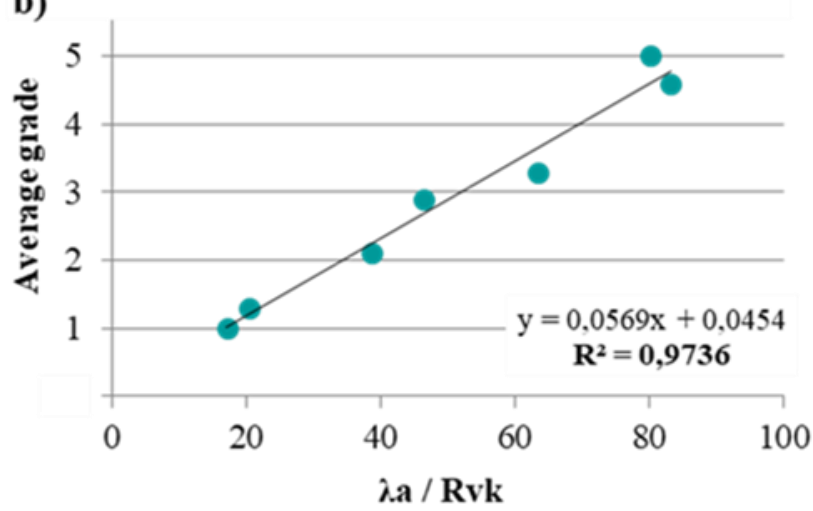

Source: Authors (2021).

The average wavelength of the profile is closely related to the spacing between irregularities. And, as already discussed, narrow gaps formed between very close surface irregularities can act as points for dirt accumulation. Now, the strong correlation found between cleanability and the ratio $\lambda \mathrm{a} / \mathrm{Rvk}$ suggests that, besides the spacing between irregularities, other profile features, represented by the parameter Rvk, play signifficant roles in the cleaning performance of the surfaces. The parameter Rvk quantifies the height of the valley zone in the material ratio curve of the surface, as shown in Figure 4. Therefore, Rvk depends both on the amplitude of the surface profile and on the distribution of material along that amplitude, which is related to the shape of the profile and of its irregularities.

For surfaces with close values of Rvk and Rpk (height of the peak zone in the material ratio curve) the distribution of material occurs in nearly equivalent way in the lower and upper portions of the profile. On the other hand, when there is a significant imbalance in the value of these parameters, an asymmetry is noted between the peak and valley zones. The surfaces Glossy Wavy and Matt, for example, with a reduced Rvk value in relation to Rpk, are characterized by a higher concentration of material in the lower portion of their profiles, since these profiles are constituted by wide valleys and high sharp peaks. In this case, the profile asymmetry seemed to contribute to avoid dirt accumulation on these surfaces. Also presenting high $\lambda \mathrm{a}$ values, the Glossy Wavy and Matt surfaces exhibited the best cleaning performances among the studied samples.

On the other hand, poor cleanability was observed for the surfaces Glossy Polished, Satin, Natural and Stone, with profiles that, albeit in a subtle way, presented the reverse asymmetry, with Rvk surpassing Rpk. The profile of the Glossy Polished surface, essentially constituted by narrow valleys, is characterized, simultaneously, by a short average wavelength and a great unbalance between Rvk and Rpk (Rvk >> Rvk). As consequence, despite the smooth touch of this surface, which by common sense, is associated to easy cleaning, a great dirt accumulation degree was observed.

\section{Conclusion}

This work evaluated the effects of pedestrian traffic on the surface profile, slip resistance and visual appearance of commercial ceramic floor tiles with different surface finishes.

The mechanical wear showed to significantly affect the profile of the floor surfaces. In general, an evident reduction of the sharpness and height of profile peaks was observed. Thus, it can be said that some of the most important characteristics of the surface profile of the flooring material to assure high slip resistance were deteriorated. As a consequence, all the surfaces 
which initially presented satisfactory PTV for use in slipping risk areas, no longer met this safety requirement after the pedestrian traffic experiment. It was also found that the surface wear and the consequent decrease of the slip resistance produced by pedestrian traffic was greater for tiles that originally presented higher slip resistance.

The dirt accumulation proved to be a factor that significantly affect the visual appearance of the surfaces. However, it was observed the that intensity of the visual appearance variation, related to the degree of dirt accumulation, varied considerably according to the characteristics of the surface profile of the floors. The results of the study suggested that surfaces with more spaced irregularities and wider profile valleys should be designed for improved cleaning performances, in order to avoid undesirable aesthetical deteriorations.

\section{Acknowledgments}

This study was financed in part by the Coordenação de Aperfeiçoamento de Pessoal de Nível Superior - Brasil (CAPES) - Finance Code 001.

It was also supported by the Conselho Nacional de Desenvolvimento Científico e Tecnológico - Brasil (CNPq) Process: 142276/2016-2.

We would also like to extend our especial gratitude to the Group of Ferroic Materials of the Physical Department of the Federal University of São Carlos for providing the profilometer for the study.

\section{References}

AS. Standards Australia. (2013). AS 4586, Slip resistance classification of new pedestrian surface materials.

ASTM. American Society for Testing and Materials. (2004). ASTM C 650. Standard Test Method for Determination of Resistance of Ceramic Tile to Chemical Substances.

ASTM. American Society for Testing and Materials. (2018). ASTM E. 303-93, Standard Test Method for Measuring Surface Frictional Properties Using the British Pendulum Tester.

BSI. British Standards Institution. (2002). BS 7976. Pendulum testers.

BSI. British Standards Institution. (2011). EN BS 13036-4. Road and airfield surface characteristics. Test methods for measurement of slip/skid resistance of a surface. The pendulum test.

Carpinetti, L. C. R., Gonçalves Filho, E. V., Porto, A. J. V., \& Jasinevicius, R. G. (2000). Rugosidade Superficial: Conceitos e Princípios de Medição, Serviço Gráfico USP - EESC, São Carlos.

Chang, W.-R. (1999). The effect of surface roughness on the measurement of slip resistance. International Journal of Industrial Ergonomics, 24 (3), $299-313$.

Chang, W.-R. (2004). Preferred surface microscopic geometric features on floors as potential interventions for slip and fall accidents on liquid contaminated surfaces, Journal of Safety Research, 35 (1), 71-79.

Chang, W.-R., Matz, S., Grönqvist, R., \& Hirvonen M. (2010). Linear regression models of floor surface parameters on friction between Neolite and Quarry tiles. Applied Ergonomics, 41 (1), 27-33.

Clarke, J. D., Hallas, K., Lewis R., Thorpe, S., Hunwin, G., \& Carré, M. J. (2015). Understanding the friction measured by standardised test methodologies used to assess shoe-surface slip risk. Journal of Testing and Evaluation, 43 (4), 723-734.

Engels, M. (2016). Novas Possibilidades de Testes Práticos para Determinação da Resistência ao Escorregamento e Limpabilidade,, Cerâmica Industrial, 20 $(5 / 6), 7-15$.

ISO. International Standards Organization. (1995). ISO 10545-1. Ceramic Tiles: Determination of chemical resistance.

Kim, I.-J. (2017). Investigation of Floor Surface Finishes for Optimal Slip Resistance Performance. Safety and Health at Work, 9 (1), 17-24.

Li, K.W., Chang, W.-R., Leamon, T. B., \& Chen, C. J. (2004). Floor slipperiness measurement: friction coefficient, roughness of floors, and subjective perception under spillage conditions. Safety Science, 42 (6) 547-565.

Lot, A. V., Menegazzo, A. P. M., Brasileiro, C. T., Melchiades, F. G., \& Boschi, A. O. (2021), Correlations Between the Slip Resistance and Surface Roughness of Ceramic Floor Tiles, Research, Society and Development, 10 (4), e4410413865.

Mitutoyo America Corporation. (1994). Mitutoyo Surface Roughness Measuring System SurfTest SURFPAK Series - Manual 4796-3G, Series 178. 
Research, Society and Development, v. 10, n. 4, e51610414425, 2021

(CC BY 4.0) | ISSN 2525-3409 | DOI: http://dx.doi.org/10.33448/rsd-v10i4.14425

Muñoz, A., Silva, G., Domínguez, R., Gilabert, J., López, M., \& Segura, M. C. (2014). Analysis of the life span of flooring slip resistance performance. Proceedings of the 13th World Congress on Ceramic Tile Quality.

Muñoz, A. (2019). Problemática del resbalamiento en pavimentos cerámicos. Memoria presentada para optar al grado de doctora por el Programa de Doctorado en Tecnologías Industriales y Materiales Escuela de Doctorado de la Universitat Jaume I.

Olympus Corporation. (2021). Medição da rugosidade de superfícies - Parâmetros. https://www.olympus-ims.com/pt/metrology/surface-roughnessmeasurement-portal/parameters/

Parra, B; S., Gennari, R. C., Melchiades, F. G., \& Boschi, A. O. (2006). Rugosidade Superficial de Revestimentos Cerâmicos. Cerâmica Industrial, 11 (2), 15 18.

Rambaldi, E., Lucchese, B., Engels, M., \& Bignozzi, M.C. (2019). Evaluation of durability and cleanability performances of protective treatments for lapped ceramic tiles - Part 2. International Journal of the Applied Ceramic Technology, 16 (2), 625-637.

Shaw, R., Lemon, P., \& Thorpe, P. (2009). Development of a more accurate assessment of roughness parameters for flooring. Health and Safety Executive Research Report 732 .

Stevension, M. G., Hoang, K., Bunterngchit, Y., \& Lloyd, D. (1989). Measurement of slip resistance of shoes on floor surfaces, Part 1: Methods. Journal of Occupational Health and Safety, 5 (2), 115-120.

Strautins, C. (2008). Sustainable slip resistance: An opportunity for innovation. Proceedings of the 10th World Congress on Ceramic Tile Quality.

UNE. Asociación Española de Normalización. (2003). UNE ENV 12633. Method to assess the slip/slide resistance of polished and unpolished flooring.

United Kingdom Slip Resistance Group. (2000). The Measurement of Floor Slip Resistance - Guidelines Recommended by the UK Slip Resistance Group. United Kingdom.

World Health Organization. (2007). WHO global report on falls prevention in older age. 53. 